\title{
Changes in Mangrove Epifaunal Assemblages Caused by Forest Logging during Hunting of the Neotropical Cormorant (Phalacrocorax brasilianus) on the Colombian Pacific Coast
}

\author{
Carlos Andrés Satizabal R. ${ }^{1}$, Jaime Ricardo Cantera Kintz ${ }^{1}$, Paula Cristina Sierra-Correa ${ }^{2}$ \\ ${ }^{1}$ Universidad del Valle, Ecology of Estuaries and Mangroves Research Group (ECOMANGLARES), Cali, Colombia \\ ${ }^{2}$ Marine and Coastal Research Institute (INVEMAR), Cerro Punta Betín, Santa Marta, Colombia \\ Email: casatiza@gmail.com
}

Received May 8, 2012; revised July 6, 2012; accepted July 15, 2012

\begin{abstract}
Although the importance of mangroves is clearly recognized around the world, these ecosystems are being strongly altered by the logging of their forests for multiple purposes. The Colombian Pacific coast is not an exception to this situation, and apart from the traditional logging of wood, the hunting of the Neotropical Cormorant or Pato-cuervo (Phalacrocorax brasilianus), an activity largely unknown but widespread in the region, is also causing the logging of great extensions of mangroves. The aim of this research was to determine if the assemblages of mollusks and crustaceans of these mangroves are being affected by the hunting of the cormorant. To answer this question, quantitative samplings were realized in four transects in logged and unlogged mangrove areas on the southwestern coast of the Colombian Pacific and diversity, equitability and dominance of macrofaunal assemblages of mangroves were calculated. The data show that although significant differences between diversity indices were not found, there were important differences in equitability (total J': 0.55 in T1, 0.77 in T2, 0.46 in T3 and 0.65 in T4), specific dominance, and composition of species (T1: 11 species, T2: 13, T3: 9 and T4: 11) between logged and unlogged areas. Based on these results, although forest structure and interstitial salinity were different among transects, we conclude that the present practice of exploitation of the Neotropical Cormorant is affecting the epifaunal populations of mangroves, causing changes in the composition and dominance of species.
\end{abstract}

Keywords: Mangrove; Mollusks; Crustaceans; Neotropical Cormorant; Colombian Pacific

\section{Introduction}

It is well known that mangrove forests are ecosystems of great ecological and economic importance, since by their nature they provide shelter, food, and protection for many species, among which are fish, crustaceans, mollusks, and many others [1-3]. The most important role of mangroves is that of "nurseries" for the birth and development of early stages of these species, representing a key role not only in the maintenance of mangroves, but also in other ecosystems, both marine and freshwater [3]. Although the importance of mangrove ecosystems is well recognized, these ecosystems are being severely altered throughout the world, because of logging for multiple purposes.

On the Colombian Pacific coast, although logging is legally prohibited, large tracts of mangrove forest are being cut, mainly for exploitation of timber resources,

"Corresponding author. but cutting also has been done historically for tannin extraction, drying out mangroves for coconut crops, or establishment of ponds for shrimp farming. An apparently new activity on a massive scale in the south of the country, about which there are few references, is the exploitation of the Neotropical Cormorant or Duck-Crow (Phalacrocorax brasilianus [Gmelin]), family Phalacrocoracidae, previously known as $P$. bougainvillii).

This species nests in the tops of mangrove trees, and the adults and young (the latter in greater proportion) are consumed locally by the surrounding human communities; this is causing cutting of large areas of forests to obtain the animals. Populations of this species are affected by both the loss of individuals by hunting and by habitat destruction, resulting in decreased reproductive success of these birds [4]. Although hunting is unprecedented anywhere else on the American Pacific coast, some authors have pointed out the effect it could have on 
the mangrove ecosystem and on plant and animal communities associated with that ecosystem [5].

The species composition of macrobenthic communities associated with mangrove ecosystems is known from a taxonomic and ecological viewpoint in some regions of the Colombian Pacific coast for both mollusks [3,6-12] and crustaceans $[3,13,14]$. Ecological studies of the communities associated with mangroves are rare in the $\mathrm{Pa}-$ cific Coast $[3,15]$, and only a few studies examine the community structure $[9,16,17]$.

Mollusks and crustaceans are the most remarkable organisms of mangroves, for both species richness and the abundance that some of them present. These two groups live on both mangrove trees and in the substrate and are known as an important part of the mangrove benthic community; they are key links in food webs of the ecosystem $[18,19]$. Although most of these species are also found on fallen logs or associated with the soil, it can be seen that the cutting of mangroves for the exploitation of Neotropical Cormorants may affect populations of these two groups and epibenthic communities in general, as has been recorded in other parts of the world [20].

The aim of this paper was to examine the impact of the cutting of mangrove forests for Neotropical Cormorant capture on the structure of the mangroves and on the composition and abundance patterns of mangrove epibenthic organisms, including crustacean and mollusk populations, on the Colombian Pacific coast.

\section{Methods}

\subsection{Study Area}

The study area was the municipality of Timbiquí, located in southwestern Colombia on the Pacific coast, between $2^{\circ} 42.213^{\prime} \mathrm{N}, 77^{\circ} 46.398^{\prime} \mathrm{W}$ and $2^{\circ} 56.515^{\prime} \mathrm{N}, 77^{\circ} 39.253^{\prime} \mathrm{W}$. The average air temperature is $28^{\circ} \mathrm{C}$, mean annual rainfall is close to $6000 \mathrm{~mm}$, and relative humidity is $93 \%$. The main rivers that supply the municipality are the Timbiquí river, the Saija, and the Bubuey. These rivers flow into the Pacific Ocean, forming wide river mouths that have tidal deltas and accumulations of sediment in coastal edges covered with mangrove vegetation. Mangroves cover an area that reaches 8545 ha. The vegetation consists mainly of white mangrove (Laguncularia racemosa), black or iguanero mangrove (Avicennia germinans), piñuelo (Pelliciera rhizophorae), nato (Mora oleifera), and red mangrove (Rhizophora mangle and Rhizophora racemosa), as well as other target species.

Rhizophora species are the most dominant and frequent individuals, with heights over $30 \mathrm{~m}$ [21].

Sampling was conducted under the project "Zoning and Management of Mangroves in the Municipality of Timbiquí", agreement No.222, INVEMAR-MAVDT.

\subsection{Sampling Areas}

In order to see whether there were differences in the composition and structure of epifaunal communities among areas subjected to logging, areas in which Cormorant hunting has been carried out, areas with other kinds of human interference, and areas without apparent intervention, four areas were selected (Figure 1): the first (Transect 1) is a mangrove area near agricultural activity with a possible effect due to this activity, the second (Transect 2) is non perturbed mangrove having higher interstitial salinity, the third (Transect 3) is an area that was recently logged to catch Neotropical Cormorants, and the fourth (Transect 4) is an area with no apparent intervention. This transect have similar salinity to transects 1 and 2 but corresponds to a well developed mangrove forest without perturbation. Research was carried out to study the characteristics of epibenthic assemblages of organisms in relation to the structure of the mangrove forest, to determine the effect that logging for hunting Cormorant, has had on the stability of the epifaunistic communities associated with mangroves.

\subsection{Study of the Structure of the Mangrove Forest}

To determine the structure of the forest, the following variables were measured for each tree in each transect, using the point-quarter method: distance to the central point $(\mathrm{m})$, species, diameter $(\mathrm{cm})$, height $(\mathrm{m})$; from these measurements density (No. of individuals/ha), basal area $\left(\mathrm{m}^{2} / \mathrm{ha}\right)$, and total height were calculated. Structure index are used to determinate the degree of perturbation of mangrove forests.

\subsection{Structure of Epibenthic Faunal Assemblages}

Sampling the epifauna associated with mangrove forest

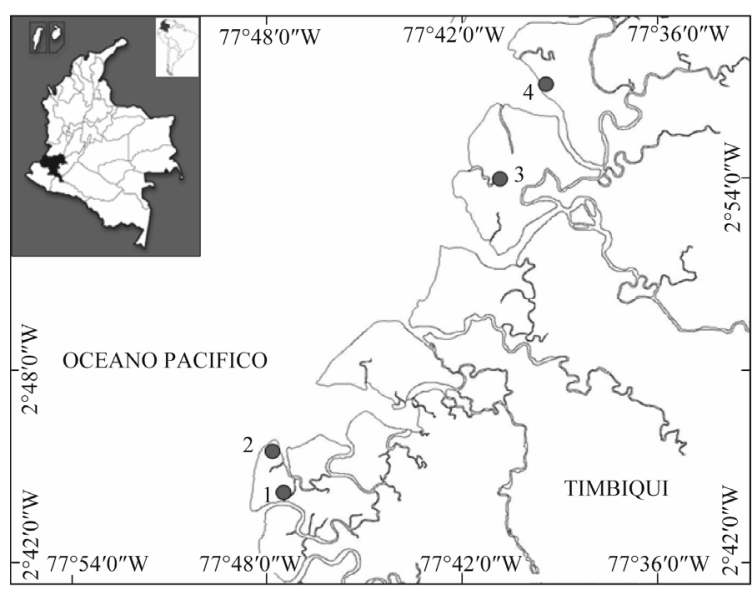

Figure 1. The study area showing the location of the four sampling mangrove areas in Pacific coast of Colombia (PCC), Tropical eastern Pacific. 
was done based on transects used for determining the structure of the forest. From this line two transects were located $10 \mathrm{~m}$ on either side of the line and parallel to it, with a length of $50 \mathrm{~m}$.

Along each transect, three quadrants of $2 \times 3 \mathrm{~m}$ were demarcated. In each of these, the number of species and number of individuals found on both the substrate and on the surface of the trees (branches, trunks and roots) were recorded. The species were identified in situ when possible, or samples were taken and fixed in alcohol for transport and laboratory identification.

With the data obtained, an analysis of similarity was carried out between areas using the Bray-Curtis index and represented in a dendrogram (cluster analysis) to determine the similarities in species composition among the four zones. Using the abundance and richness data, Shannon-Wiener diversity index (H'), Pielou equitability (J') and Simpson dominance (D) were calculated using the Biodiversity Pro software ${ }^{\circledR}$ Version 2.

The indices found were compared between the study areas by a two-factor analysis of variance ANOVA (transect and quadrant) and a Duncan test to determine which data sets were causing this difference. These tests were conducted using SPSS $^{\odot} 15.0$ software and STATISTICA $7.0^{\circ}$.

\section{Results}

\subsection{Structure of the Mangrove Forest}

We found significant differences in the structural characteristics of mangrove forests in the four zones (Table 1). Transect one (T1) presents data indicating that the forest is in good condition but is still somewhat influenced by the practice carried out in adjacent agricultural areas. In transect two (T2) the forest has good structural properties; this is the closest area to another area logged for the capture of the Neotropical Cormorant, so presumably this is the state of naturally occurring forest that is used by the birds and later is logged.

In transect three (T3) trees appear very thin and small, corresponding to an area that was logged recently to catch Neotropical Cormorants, and which is in process of regeneration. Transect four (T4) is an area without intervention that has relatively tall trees, with an average of $19 \mathrm{~m}$, and its average density is characteristic of well-developed forest. Structural index show that the mangroves of Transects 1,2 and 4.

\subsection{Structure of Epibenthic Faunal Assemblages}

A list of the species found and their abundances in each transect is shown in Table 2. This table records two species of the genus Anadara, because, although these species are end of aunistic, they were found on the surface of the substrate and therefore were included on the list. Based on the results of richness and abundance taken in the area, diversity, equitability and dominance indices were determined for both mollusks and crustaceans together and for each group separately. The results are shown in Table 3; the boxes marked with an asterisk (*) correspond to areas where only one species was found. Transect with the highest richness is T2 and the highest abundance is T4. T3 has a high number of individuals, but the $49 \%$ is of one species. Dominance was the highest in T3 (0.336) and lowest in T2 (0.123).

The mollusks showed the highest similarity between T4 and T2 (80\%) (Figure 2(a)), while crustaceans had greater similarity between T4 and T1 (85.7\%) (Figure 2(b)). When data for the two groups were combined, they showed a grouping similar to that of crustaceans, also showing an association of T1 with $\mathrm{T} 4(73.7 \%)$ and $\mathrm{T} 3$ with T2 (78.3\%), as seen in Figure 2(c).

The results of the ANOVA can be seen in Table 4. The only significant difference between the studied transects occurred in the diversity index $\left(\mathrm{H}^{\prime}\right)$ for mollusks, and the equitability index $\left(\mathrm{J}^{\prime}\right)$ for mollusks and crustaceans together.

The results of Duncan's test for equitability of the epifauna can be seen in Table 5, where boxes marked (*) show a significant difference. T3 transect data are notably different with the other areas, especially in the last quadrant $(3.3\{6\})$, which corresponds to the more internal area of logged forest for the exploitation of the Neotropical Cormorant. The data in this quadrant show significant differences from many of the data in the other transects.

Table 1. Structural characteristics of the mangrove forest and interstitial salinity for each studied transect in mangrove area of Timbiqui (PCC).

\begin{tabular}{|c|c|c|c|c|c|c|c|c|}
\hline \multirow{2}{*}{ Transect } & \multirow{2}{*}{ Density (Ind/ha) } & \multicolumn{3}{|c|}{ Mean high (m) } & \multirow{2}{*}{ High max. (m) } & \multirow{2}{*}{ Basal area $\left(\mathrm{m}^{2} / \mathrm{ha}\right)$} & \multicolumn{2}{|c|}{ Salinity (ups) } \\
\hline & & Seedlings & Saplings & Taper & & & Outside & Inside \\
\hline 1 & 1474 & 6.0 & 8.0 & 16.0 & 25 & 45 & 9.4 & 8.6 \\
\hline 2 & 2090 & 6.0 & 10.0 & 17.0 & 35 & 119 & 18.3 & 14.8 \\
\hline 3 & 776 & 5.0 & 9.0 & 13.0 & 17 & 11 & 6.8 & 4.9 \\
\hline 4 & 642 & 5.0 & 8.0 & 19.0 & 25 & 20 & 7.6 & 4.2 \\
\hline
\end{tabular}


Table 2. Species of mollusks and crustaceans and their abundances found in four transects in the mangrove zone of Timbiquí (PCC).

\begin{tabular}{|c|c|c|c|c|c|c|}
\hline Groups & Family & Species & T1 & T2 & T3 & T4 \\
\hline \multirow{9}{*}{ Mollusks } & \multirow{2}{*}{ Arcidae } & Anadara tuberculosa & 1 & 5 & 0 & 3 \\
\hline & & Anadara similis & 0 & 0 & 0 & 1 \\
\hline & \multirow{3}{*}{ Littorinidae } & Littoraria zebra & 1 & 1 & 6 & 39 \\
\hline & & Littoraria fasciata & 6 & 1 & 0 & 36 \\
\hline & & Littorina scabra & 1 & 0 & 0 & 0 \\
\hline & \multirow{2}{*}{ Potamididae } & Cerithidea mazatlanica & 16 & 2 & 52 & 32 \\
\hline & & Cerithidea pulchra & 1 & 5 & 2 & 0 \\
\hline & Teredinidae & Teredo sp. & 0 & 0 & 100 & 0 \\
\hline & Muricidae & Thais kiosquiformis & 1 & 0 & 35 & 95 \\
\hline \multirow{9}{*}{ Crustaceans } & \multirow{3}{*}{ Grapsidae } & Goniopsis pulchra & 7 & 7 & 2 & 3 \\
\hline & & Aratus pisonii & 0 & 5 & 0 & 2 \\
\hline & & Pachigrapsus tranversus & 6 & 2 & 4 & 3 \\
\hline & Gercarcinidae & Gecarcinus sp. & 0 & 2 & 0 & 0 \\
\hline & \multirow{2}{*}{ Ocypodidae } & Uca sp. 1 & 1 & 11 & 2 & 1 \\
\hline & & Uca sp. 2 & 0 & 6 & 1 & 1 \\
\hline & Chthamalidae & Chthamalus panamensis & 0 & 1 & 0 & 0 \\
\hline & Xanthidae & Eurypanopeus transversus & 1 & 1 & 0 & 0 \\
\hline & Total & & 42 & 49 & 204 & 216 \\
\hline
\end{tabular}

Table 3. Indices of diversity $\left(\mathrm{H}^{\prime}\right)$, equitability $\left(\mathrm{J}^{\prime}\right)$, and dominance $(\mathrm{D})$ for each quadrant and total per transect of epibenthic fauna of a mangrove area of Timbiquí (PCC).

\begin{tabular}{|c|c|c|c|c|c|}
\hline \multirow{2}{*}{ Line } & \multirow{2}{*}{ quadrant } & \multirow{2}{*}{ Repetition } & \multicolumn{3}{|c|}{ Index } \\
\hline & & & $\mathbf{H}^{\prime}$ & $\mathbf{J}^{\prime}$ & D \\
\hline 4 & 1 & 1 & 0.367 & 0.472 & 0.574 \\
\hline 4 & 1 & 2 & 0.528 & 0.625 & 0.382 \\
\hline 4 & 2 & 1 & 0.687 & 0.882 & 0.192 \\
\hline 4 & 2 & 2 & 0.627 & 0.805 & 0.271 \\
\hline 4 & 3 & 1 & 0.567 & 0.942 & 0.231 \\
\hline 4 & 3 & 2 & 0.540 & 0.898 & 0.304 \\
\hline T4 & -- & -- & 1.548 & 0.645 & 0.276 \\
\hline 3 & 1 & 1 & 0.815 & 0.782 & 0.228 \\
\hline 3 & 1 & 2 & 0.441 & 0.567 & 0.471 \\
\hline 3 & 2 & 1 & 0.476 & 0.681 & 0.424 \\
\hline 3 & 2 & 2 & 0.618 & 0.795 & 0.292 \\
\hline 3 & 3 & 1 & 0.196 & 0.252 & 0.802 \\
\hline 3 & 3 & 2 & 0.354 & 0.589 & 0.543 \\
\hline T3 & -- & -- & 1.025 & 0.467 & 0.336 \\
\hline 2 & 1 & 1 & 0.450 & 0.747 & 0.373 \\
\hline 2 & 1 & 2 & 0.647 & 0.831 & 0.220 \\
\hline 2 & 2 & 1 & 0.460 & 0.764 & 0.399 \\
\hline 2 & 2 & 2 & 0.673 & 0.963 & 0.095 \\
\hline 2 & 3 & 1 & 0.636 & 0.910 & 0.167 \\
\hline 2 & 3 & 2 & 0.297 & 0.985 & 0.429 \\
\hline T2 & -- & -- & 1.851 & 0.722 & 0.124 \\
\hline 1 & 1 & 1 & 0.415 & 0.870 & 0.333 \\
\hline 1 & 1 & 2 & 0.697 & 0.896 & 0.167 \\
\hline 1 & 2 & 1 & 0.308 & 0.511 & 0.637 \\
\hline 1 & 2 & 2 & 0.391 & 0.819 & 0.393 \\
\hline 1 & 3 & 1 & 0.437 & 0.726 & 0.434 \\
\hline $1^{*}$ & 3 & 2 & & & \\
\hline T1 & -- & -- & 1.326 & 0.553 & 0.217 \\
\hline
\end{tabular}

"Zone in which only one species was found. 
Table 4. ANOVA, two factors $(\alpha=0.05)\left(H^{\prime}=\right.$ epifaunal diversity, $J^{\prime}=$ epifaunal equitability, $D=$ epifaunal dominance).

\begin{tabular}{|c|c|c|c|c|c|c|}
\hline & & deg. of freedom & SS & MS & $\mathbf{F}$ & $\mathbf{p}$ \\
\hline \multirow{4}{*}{$\mathbf{H}^{\prime}$} & TRANSECT & 3 & 0.111191 & 0.037064 & 1.2859 & 0.323812 \\
\hline & QUADRANT & 2 & 0.135944 & 0.067972 & 2.3583 & 0.136834 \\
\hline & Transect*Quadrant & 6 & 0.171889 & 0.028648 & 0.9940 & 0.471531 \\
\hline & Error & 12 & 0.345868 & 0.028822 & & \\
\hline \multirow{4}{*}{$\mathbf{J}^{\prime}$} & TRANSECT & 3 & 0.21338 & 0.07113 & 3.9981 & $0.034636^{*}$ \\
\hline & QUADRANT & 2 & 0.01891 & 0.00945 & 0.5314 & 0.600998 \\
\hline & Transect*Quadrant & 6 & 0.33116 & 0.05519 & 3.1025 & $0.045013 *$ \\
\hline & Error & 12 & 0.21348 & 0.01779 & & \\
\hline \multirow{4}{*}{ D } & TRANSECT & 3 & 0.191070 & 0.063690 & 1.9499 & 0.175464 \\
\hline & QUADRANT & 2 & 0.117047 & 0.058523 & 1.7917 & 0.208496 \\
\hline & Transect*Quadrant & 6 & 0.312188 & 0.052031 & 1.5930 & 0.231674 \\
\hline & Error & 12 & 0.391953 & 0.032663 & & \\
\hline
\end{tabular}

Table 5. Duncan test for equitability of the epifaunistic community (J'). Interaction 1 × 2 (1-Transect, 2-Quadrant).

\begin{tabular}{|c|c|c|c|c|c|c|c|c|c|c|c|c|c|}
\hline & & $\{1\}$ & $\{2\}$ & $\{3\}$ & $\{4\}$ & $\{5\}$ & $\{6\}$ & $\{7\}$ & $\{8\}$ & $\{9\}$ & $\{10\}$ & $\{11\}$ & $\{12\}$ \\
\hline 4 & $1\{1\}$ & & 0.069 & $0.030 *$ & 0.387 & 0.212 & 0.356 & 0.125 & 0.057 & $0.022 *$ & $0.046^{*}$ & 0.400 & 0.056 \\
\hline 4 & $2\{2\}$ & 0.069 & & 0.609 & 0.263 & 0.467 & $0.015^{*}$ & 0.690 & 0.889 & 0.491 & 0.789 & 0.245 & 0.886 \\
\hline 4 & $3\{3\}$ & $0.030^{*}$ & 0.609 & & 0.125 & 0.242 & $0.007 *$ & 0.389 & 0.694 & 0.840 & 0.786 & 0.114 & 0.699 \\
\hline 3 & $1\{4\}$ & 0.387 & 0.263 & 0.125 & & 0.643 & 0.102 & 0.430 & 0.223 & 0.093 & 0.184 & 0.944 & 0.221 \\
\hline 3 & $2\{5\}$ & 0.212 & 0.467 & 0.242 & 0.643 & & 0.050 & 0.709 & 0.406 & 0.184 & 0.343 & 0.612 & 0.402 \\
\hline 3 & $3\{6\}$ & 0.356 & $0.015^{*}$ & $0.007 *$ & 0.102 & 0.050 & & $0.028 *$ & $0.012 *$ & $0.005^{*}$ & $0.010 *$ & 0.106 & $0.012 *$ \\
\hline 2 & $1\{7\}$ & 0.125 & 0.690 & 0.389 & 0.430 & 0.709 & $0.028^{*}$ & & 0.614 & 0.304 & 0.531 & 0.406 & 0.608 \\
\hline 2 & $2\{8\}$ & 0.057 & 0.889 & 0.694 & 0.223 & 0.406 & $0.012^{*}$ & 0.614 & & 0.570 & 0.886 & 0.205 & 0.997 \\
\hline 2 & $3\{9\}$ & $0.022 *$ & 0.491 & 0.840 & 0.093 & 0.184 & $0.005^{*}$ & 0.304 & 0.570 & & 0.654 & 0.084 & 0.572 \\
\hline 1 & $1\{10\}$ & $0.046^{*}$ & 0.789 & 0.786 & 0.184 & 0.343 & $0.010^{*}$ & 0.531 & 0.886 & 0.654 & & 0.168 & 0.889 \\
\hline 1 & $2\{11\}$ & 0.400 & 0.245 & 0.114 & 0.944 & 0.612 & 0.106 & 0.406 & 0.205 & 0.084 & 0.168 & & 0.204 \\
\hline 1 & $3\{12\}$ & 0.056 & 0.886 & 0.699 & 0.221 & 0.402 & $0.012 *$ & 0.608 & 0.997 & 0.572 & 0.889 & 0.204 & \\
\hline
\end{tabular}

\section{Discussion}

The results of the study showed that the logging of mangroves to capture Neotropical Cormorants affects the size and development of mangroves and, in consequence, the composition, species dominance, and equitability of epibenthic communities, although the diversity indices show small differences. Although pacific Colombian mangroves have relatively low diversity and richness, all studied index had lower values in T3 (where is the impact of the mangrove logging to capture cormorant nestlings) than the other three transects. In terms of species composition, diversity and evenness the groups formed indicate differences between Transects with high (T3) and low (T1, T2 and T4) perturbation due to the capture of the cormorant; although some areas had different structural characteristics at the time of the study (T1 mangroves slightly affected, $\mathrm{T} 2$ non perturbed mangroves but geographically close to an area with strong perturbations and T4 unaffected mangroves). These places are similar estuarine mangrove areas, which means that they possibly had a similar species composition. This is particularly notably in the areas where transects two (T2) and three (T3) were located, which served as nesting sites for Neotropical Cormorants; however, T3 suffered exploitation of the bird and has a forest with completely different characteristics, with a structure that indicates a low level of development, in a state of regeneration. The differences in species composition of epifauna in these areas are due to changes in the structural characteristics of the forest, which have led to the emergence of species that are able to rapidly colonize these environments; these species are found naturally in any ecosystem that has been altered repeatedly or at such a high level as presented in this area [22]. In the mangroves studied, the remains of trees left on the substrate as a result of logging have resulted in the proliferation and abundance of two species: Thais kiosquiformis and Teredo sp., which 

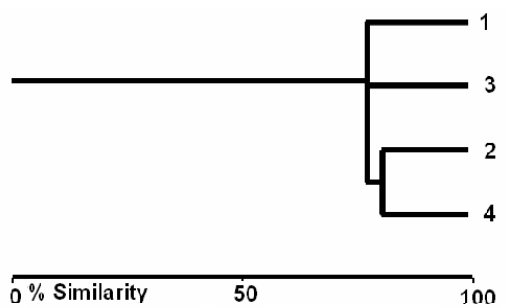

(a)
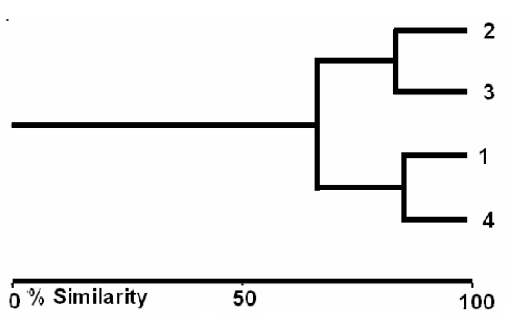

(b)

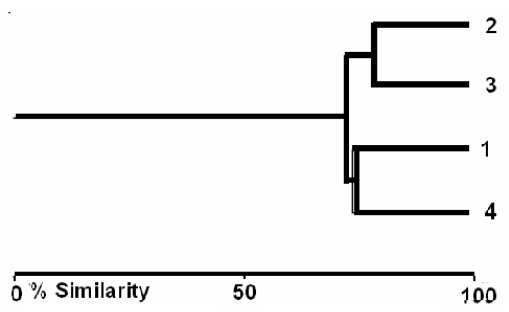

(c)

Figure 2. Cluster analysis by transect for epibenthic fauna of mangroves in Timbiquí (PCC). (a) Mollusks; (b) Crustaceans; (c) Mollusks and crustaceans combined.

are found in decaying logs, which provide shelter and defense against desiccation $[23,24]$. Both are species that live in other mangroves when there are many dead trunks. The abundance of these species in T3 (where logging has occurred) is the main factor that modifies the structure of assemblages of mangrove epifauna. Crustacean species such as Pachygrapsus transversus and Goniopsis pulchra, can support large changes in habitat conditions $[25,26]$ and therefore can inhabit in all mangrove areas. Unlike, some littorinids and Aratus pisonii are not present in perturbed mangrove.

This is why the differences in diversity are small, which is different than expected for the different areas. However, this is not surprising; because these indices take into account both abundance and species richness, resulting in the modification of both at different levels without altering the value of the index.

The results found in this research coincide with the models presented in other works [22], which indicated that the effects on diversity of a disturbance such as intensive logging of mangroves for capturing Neotropical Cormorants are real. Changes do occur in species richness and abundance of individuals, reflected in the dominance and equitability of the species, more than in the diversity index. The decrease in the number of individuals of different species has been found in other studies $([20,27])$, which examined the effect of various types of disturbance on mangrove forests, including logging for other purposes different to capture birds.

\section{Conclusion}

It can be concluded that the exploitation of Neotropical Cormorants by the current practice of logging the forest, in addition to causing significant alterations in the structure of mangroves, also affects the structure of assemblages of epifaunistic mollusks and crustaceans that inhabit them. These changes are manifested mainly in the composition, dominance, and equitability of the species, and slightly in species diversity, where the physical and chemical changes in the ecosystem caused by vegetation change, salinity among others, cause the disappearanceappearance and/or proliferation of a few species that are favored by the new features of the habitat. These changes could have a significant economic impact on the inhabitants of the Pacific coast, given its dependence to a large extent on the resources provided by the mangrove ecosystem. This study is an input to management of this mangrove ecosystem and its associated avifauna.

\section{Acknowledgements}

The authors express their gratitude to the Institute of Marine and Coastal Research-INVEMAR, through which this work was developed in the framework of the project "zoning and management of mangroves in the municipality of Timbiquí", agreement No. 222 INVEMARMAVDT, and all people linked to this project, who contributed significantly: A. Sanchez, C. Muñoz, F. Bedoya, A. Moreno. We also thank the Research Group in Estuaries and Mangroves (ECOMANGLARES), and its members J. F. Lazarus, A. M. Cobo, L. A. Lopez de Mesa, E. Londoño, L. Herrera and M. A. Ocampo for their support in identifying individuals and statistical analysis. We are grateful to the professor Philip A. Silverstone-Sopkin of the Universidad del Valle for correcting the English grammar.

\section{REFERENCES}

[1] E. J. Heald and W. E. Odum, "The Contribution of Mangrove Swamps to Florida Fisheries," Proceedings of Gulf and Caribbean Fisheries Institute, Vol. 22, 1970, pp. 130-135.

[2] W. E. Odum and E. J. Heald, "Mangrove Forest and Aquatic Productivity," In: J. T. Teas and S. C. Sneaker, Eds., An Introduction to Land-Water Interactions, Springer-Verlag Ecological Study Series, New York, 1975, pp. 135.

[3] H. Von Prahl, J. R. Cantera and J. R. Contreras, "Man- 
groves and Mens of the Colombian Pacific," FEN/COLCIENCIAS, Editorial Presencia, Bogotá, 1990.

[4] R. Johnston, "Population Size, Habitat and Conservation of Neotropical Cormorant (Phalacrocorax brasilianus) in the Natural National Park Sanquianga (Nariño, Colombia)," Biology Undergraduate Thesis, Universidad del Valle, Cali, 2000.

[5] Y. Cifuentes, "Reproductive Success of Phalacrocorax brasilianus (Aves: Pelecaniformes) and Its Relation to the Cutting of Trees in the Natural National Park Sanquianga Nariño, Colombia," Biology Undergraduated Thesis, Pontificia Universidad Javeriana, Bogotá, 2005.

[6] R. Contreras and J. R. Cantera, "Notes about Ecology of Molluscs Associated with Mangrove-Estuary Ecosystem in the Colombian Pacific Coast. Memories First Seminar above the South American Pacific Ocean," Memorias Primer Seminario Sobre el Océano Pacifico Sudamericano, Vol. 2, Cali, 1978.

[7] P. Ocampo and J. R. Cantera, "Molluscs Associated with Major Ecosystems of Utría Cove, Colombian Pacific," Memories VI National Marine Science Seminar, Bogotá, 1988.

[8] S. Escallón and J. R. Cantera, "Marine Mollusks of Málaga Bay, Colombian Pacific Coast: I. Pelecypoda," Scientific Bulletin de la Salle University, Vol. 3, No. 2, 1989, pp. 159-178.

[9] J. R. Cantera, "Shallow-Water Venerid Clams from the Pacific Coast of Colombia," The Veliger, Vol. 34, No. 1, 1991, pp. 78-84.

[10] A. M. Vélez, "Composition and Spatial Distribution of the Malacofauna of the Utría's Cove (Choco, Colombian Pacific)," Biology Undergraduated Thesis, Pontificia Universidad Javeriana, Santafé de Bogota, 1993.

[11] J. F. Blanco and J. R. Cantera, "The Family Conidae (Mollusca: Gastropoda) in the Colombian Pacific," Ecotrópica, Vol. 27, 1994, pp. 19-39.

[12] INVEMAR, UNIVALLE, INCIVA, "Biomálaga: Assessment of Marine and Coastal Biodiversity of Malaga Bay (Valle del Cauca), as One of the Instruments Necessary to Be Considered a Protected Area," INVEMAR-UNIVALLE-INCIVA, Cali, 2006.

[13] H. von Prahl, "Importance of Mangroves in the Biology of Penaeid Shrimp," Seminar Memories about the Scientific Study and the Human Impact on the Mangrove Ecosystem, UNESCO, Cali, 1980.

[14] J. F. Lazarus and J. R. Cantera, "Crustaceans (Crustacea: Sessilia, Stomatopoda, Isopoda, Amphipoda, Decapoda) of Malaga Bay, Valle del Cauca (Colombian Pacific)," Biota Colombiana, Vol. 8, No. 2, 2007, pp. 221-239.

[15] H. von Prahl, "Mangroves of Colombia," Villegas Editores, Bogotá, 1989.

[16] J. R. Cantera, P. M. Arnaud and R. Neira, "The Macrofauna of Sandy Beaches in Buenaventura and Malaga Bay (Colombian Pacific): Spatial Structure and Temporal
Dynamics Colombia," Journal of the Science Faculty Universidad del Valle, Vol. 10, 1994, pp. 27-48.

[17] C. A. Satizabal, "Determination of the Indirect Effect of Mangrove Cutting off for Hunting of the Duck-Crow or Neotropical Cormorant Phalacrocorax brasilianus (Aves: Phalacrocoracidae) on Epifauna at the Municipality of Timbiquí (Department of Cauca, Colombian Pacific)," Biology Undergraduate Thesis, Universidad del Valle, Cali, 2008.

[18] C. Serrato and N. E. Ayala, "Evaluation of Water Quality of the Middle and Lower Watersheds Calima River by the Reflection of Macroinvertebrate Communities," Memories 1st Congress of Biodiversity, Minambiente-Proyecto Biopacífico, Cali, 1994.

[19] I. C. Romero, "Foliar Herbivory as Mass Transfer Process in the Mangrove Ecosystem (Buenaventura Bay)," Biology Undergraduated Thesis, Universidad del Valle, Cali, 1998.

[20] C. Tovilla-Hernández, G. de La Lanza-Espino and D. E. Orihuela-Belmonte, "Impact of Logging on a Mangrove Swamp in South Mexico: Cost/Benefit Analysis," Revista de Biologia Tropical, Vol. 49, No. 2, 2001, pp. 571-580.

[21] H. Sánchez and R. Álvarez, "Diagnostic and Zonification of Colombian Pacific Mangroves," Ministry of Environment, Santa Fe de Bogotá D.C., 1997.

[22] R. L. Mackey and D. J. Currie, "A Re-Examination of the Expected Effects of Disturbance on Diversity," Oikos, Vol. 88, No. 3, 2000, pp. 483-493. doi:10.1034/j.1600-0706.2000.880303.x

[23] J. R. Cantera, R. Contreras, F. Borrero, E. Buttkus and F. Zapata, "Natural History of Mangle Gastropod Thais kiosquiformis Duclos, 1832 in the Colombian Pacific Coast," The Western Society of Malacologist, Annual Report, Vol. 12, 1979, pp. 170-194.

[24] K. E. Hoagland, "Effects of Temperature, Salinity, and Substratum on Larvae of the Shipworms Teredo bartschi Clapp and T. navalis Linnaeus (Bivalvia: Teredinidae)," American Malacological Bulletin, Vol. 4, No. 1, 1986, pp. 89-99.

[25] L. G. Abele, P. J. Campanella and M. Salmon, "Natural History and Social Organization of the Semiterrestrial Grapsid Crab Pachygrapsus transversus (Gibbes)," Journal of Experimental Marine Biology and Ecology, Vol. 104, 1986, pp. 153-170. doi:10.1016/0022-0981(86)90102-4

[26] E. E. Spivak, "Southwestern Atlantic Estuarine Crabs $\left(25^{\circ} \mathrm{S}-41^{\circ} \mathrm{S}\right)$ (Crustacea: Decapoda: Brachyura)," Investigaciones Marinas Valparaíso, Vol. 25, 1997, pp. 105120.

[27] A. M. Ellison and E. J. Farnsworth, "Anthropogenic Disturbance of Caribbean Mangrove Ecosystems: Past Impacts, Present Trends, and Future Predictions," Biotropica, Vol. 28, No. 4, 1996, pp. 549-565. doi.org/10.2307/2389096 